\title{
RECOVERY PERAK DARI LIMBAH FOTOGRAFI MELALUI MEMBRAN CAIR BERPENDUKUNG DENGAN SENYAWA PEMBAWA ASAM DI-2-ETIL HEKSILFOSFAT (D2EHPA)
}

\author{
M. C. Djunaidi, D. S. Widodo dan S. Anwar*)
}

\begin{abstract}
Abstrak
Telah dilakukan penelitian tentang recovery perak dari limbah cuci cetak dengan metode membran cair berpendukung (SLM). Sebagai membran pendukung digunakan PTFE yang direndam selama 2 jam dalam senyawa pembawa D2EHPA $1 \mathrm{M}$ dengan pelarut kerosen dan dilakukan pengadukan selama 6 jam. Untuk mengetahui kondisi optimum dalam recovery perak dilakukan variasi $p H$ larutan umpan $1 ; 1,5 ; 2 ; 2,5 ; 3 ; 3,5 ; 4$, larutan penerima $\mathrm{HCl}$; $\mathrm{HCl}-\mathrm{EDTA} ; \mathrm{HNO}_{3} ; \mathrm{HNO}_{3}-\mathrm{EDTA} ; \mathrm{H}_{3} \mathrm{PO}_{4}$; $\mathrm{H}_{3} \mathrm{PO}_{4}$-EDTA serta konsentrasi larutan limbah pemekatan $1 / 2$ kali; pengenceran 0 kali; pengenceran 10 kali. Dari penelitian ini diperoleh \% transpor perak dari limbah fotografi dengan variasi $p H$ larutan umpan memberikan \% transpor perak optimum pada pH 2,5 yaitu 96,44\% dengan larutan penerima $\mathrm{HCl}$, sedangkan untuk \% transpor perak pada fasa penerima dengan variasi larutan penerima memberikan hasil optimum pada larutan penerima (HCl-EDTA) yaitu 63,85\% dan untuk variasi konsentrasi larutan umpan memberikan hasil optimum pada pengenceran 10 kali. Dapat disimpulkan bahwa kondisi optimum untuk proses recovery perak dari limbah fotografi yaitu $p H$ larutan umpan 2,5 dengan larutan penerima $\mathrm{HCl}$. Sedangkan pada variasi larutan penerima diperoleh hasil optimum pada larutan penerima EDTA-HCl dan pada variasi konsentrasi limbah fotografi, konsentrasi paling encer memberikan hasil optimum dalam proses recovery perak dari limbah fotografi.
\end{abstract}

Kata kunci : recovery perak; membran cair; limbah fotografi

\section{Pendahuluan}

Perak merupakan logam berharga yang digunakan dalam film foto karena sifat fotosensitifnya. Pengembangan film menyebabkan limbah fotografi mengandung Ag pada larutan fixer dan air bilasan masing-masing sebesar 1.000-10.000 dan 50-200 mg/L. Perak merupakan zat yang berbahaya sehingga harus dipungut kembali (recovery) secara sempurna baik dari segi ekonomi maupun alasan lingkungan (Songkroah et al., 2003).

Berbagai teknologi digunakan untuk mendapatkan kembali Ag dari limbah fotografi dimana kebanyakan efektif pada batas konsentrasi Ag tertentu. Perak dalam bentuk kompleks anionik tiosulfat $\left[\mathrm{Ag}\left(\mathrm{S}_{2} \mathrm{O}_{3}\right)_{2}\right]^{3-}$ dapat dipisahkan dari larutannya dengan cara elektrolisis, pergantian logam (metalic replacement), pengendapan, penukar ion, membran cair emulsi (ELM), dan adsorpsi dengan kitin (Songkroah et al., 2003).

Teknik elektrolisis dan pergantian logam merubah senyawa kompleks perak tiosulfat menjadi logam Ag, sedangkan teknik pengendapan akan mengubah kompleks Ag menjadi bentuk endapan dengan penambahan agen pengendap seperti sodium sulfida, sodium borohidrida atau sodium dithionit.
Metode elektrolisis keuntungannya yaitu mendapatkan kemurnian Ag yang besar namun metode ini hanya dapat digunakan pada konsentrasi perak yang tinggi (larutan fixer). Metode pengendapan dan pergantian logam keuntungannya adalah biaya operasinya relatif murah namun menghasilkan endapan yang tidak murni sehingga membutuhkan pemurnian lebih lanjut. Selain itu metode ini tidak dapat digunakan pada konsentrasi $\mathrm{Ag}^{+}$kurang dari $100 \mathrm{mg} / \mathrm{L}$. Metode resin penukar anion hanya efektif digunakan pada konsentrasi $\mathrm{Ag}^{+}$ yang kecil yaitu kurang dari $1 \mathrm{mg} / \mathrm{L}$ dan biaya operasinya mahal (Songkroah et al., 2003). Salah satu teknik yang dapat dipakai untuk tujuan di atas adalah dengan menggunakan metode Supported Liquid Membrane atau membran cair berpendukung yang selanjutnya disingkat SLM.

Pada masa kini metode membran cair berpendukung telah mendapat perhatian sebagai suatu teknik pemisahan alternatif untuk analit ion dari larutan encer. Keuntungan dari SLM adalah bahwa kebutuhan ekstraktan/senyawa pembawa yang digunakan untuk ekstraksi sedikit, pengoperasiannya sederhana dan biayanya murah (Misra dan Gill, 1996).

\footnotetext{
$\left.{ }^{*}\right)$ Jurusan Kimia Fakultas MIPA Universitas Diponegoro

Jl. Prof. Sudarto, SH, Tembalang-Semarang 50239
} 
Penelitian recovery perak dari limbah cuci cetak dengan metode ELM telah dilakukan oleh Santoso (2000) dan Hadikawuryan (2005). Dalam limbah ini $\mathrm{Ag}^{+}$berada dalam bentuk $\mathrm{Ag}\left(\mathrm{S}_{2} \mathrm{O}_{3}\right)_{2}{ }^{3-}$. Santoso menggunakan zat pembawa dimetil dioktadesil amonium bromida (penukar anion) dalam kerosen dan surfaktan SPAN 80 dengan efisiensi transpor perak sebesar 77,33\%, sedangkan Hadikawuryan menggunakan D2EHPA-TBP $1 \mathrm{M}$ dalam kerosen dan surfaktan SPAN 80 dengan efisiensi transpor perak sebesar 89,27\%. Untuk memperoleh $\mathrm{Ag}^{+}$di fasa internal dilakukan proses pemecahan emulsi, yang tidak diperlukan pada metode SLM.

Rahmawati (2005) menggunakan metode SLM untuk mengambil perak dari larutan limbah buatan yang mengandung perak dan timbal. Sebagai membran pendukung digunakan (politetrafluoroetilen) PTFE dengan pembawa D2EHPA dalam kerosen. Persen transpor ion perak tertinggi diperoleh pada $\mathrm{pH}$ fasa umpan 3 dan fasa penerima 0,74 dengan $\mathrm{HCl}$ sebagai fasa penerima yaitu sebesar $82 \%$. Melihat hal di atas, pengambilan perak dari limbah fotografi dengan metode SLM sangatlah menarik.

Pada penelitian ini dilakukan pemisahan ion $\mathrm{Ag}^{+}$ dari larutan limbah fotografi menggunakan SLM dengan senyawa pembawa D2EHPA yang diimpregnasikan ke dalam membran PTFE. Transpor ion logam pada SLM sangat bergantung pada konsentrasi ion logam sebagai spesies yang akan dipisahkan dan agent stripping yang dapat membantu proses pelepasan ion logam dari senyawa pembawa dalam membran. Unjuk kerja senyawa pembawa D2EHPA dan penguraian kompleks $\left[\mathrm{Ag}\left(\mathrm{S}_{2} \mathrm{O}_{3}\right)_{2}\right]^{3-}$ sangat tergantung pada $\mathrm{pH}$.

\section{Metode Penelitian Variabel}

Variabel yang diuji adalah konsentrasi ion logam dalam fasa penerima dan fasa umpan, serta konsentrasi ion $\mathrm{H}^{+}$di larutan umpan dan penerima. Kondisi yang dipertahankan tetap adalah konsentrasi D2EHPA (1 M), lama perendaman PTFE (2 jam), lama pengadukan (6 jam), kecepatan pengadukan (100 rpm), volume larutan umpan dan fasa penerima (masing-masing $100 \mathrm{~mL}$ ).

\footnotetext{
Alat dan bahan

Peralatan yang digunakan meliputi peralatan gelas laboratorium, Seperangkat sel pemisahan SLM tunggal, pH meter (HACH E C20), Spektrometer serapan atom Hitachi; sedangkan bahan-bahan yang dipakai adalah larutan sampel limbah fotografi, Kerosen, D2EHPA (SIGMA), Membran Politetrafluoroetilen-whatman (PTFE), $\mathrm{HCl} 37$ \% (G.R),

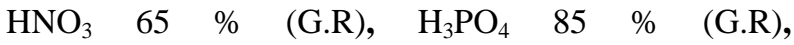
$\mathrm{Na}_{2} \mathrm{H}_{2}$ EDTA. $2 \mathrm{H}_{2} \mathrm{O}$
}

\section{Pelaksanaan Percobaan \\ Preparasi larutan umpan}

Larutan umpan yang digunakan adalah sampel limbah fotografi yang diencerkan 0 kali, 10 kali dan pemekatan $1 / 2$ kali. Masing-masing larutan hasil pengenceran dan pemekatan dibuat pHnya sebesar 1 ; 1,5; 2; 2,5; 3; 3,5 dan 4, dengan menambahkan asam nitrat.

\section{Preparasi larutan penerima}

Larutan penerima yang digunakan adalah larutan $\mathrm{HNO}_{3}, \mathrm{HNO}_{3}$-EDTA, $\mathrm{HCl}, \mathrm{HCl}$-EDTA, $\mathrm{H}_{3} \mathrm{PO}_{4}$ dan $\mathrm{H}_{3} \mathrm{PO}_{4}$-EDTA dengan nilai $\mathrm{pH}$ sebesar 0,75 .

\section{Preparasi larutan D2EHPA 1 M}

Larutan D2EHPA 95 \% diambil sebanyak 8,65 $\mathrm{mL}$, kemudian dimasukkan ke dalam labu takar 25 $\mathrm{mL}$ dan diencerkan dengan kerosen sampai tanda batas.

\section{Preparasi larutan EDTA 0.01 M}

Padatan $\mathrm{Na}_{2} \mathrm{H}_{2}$ EDTA. $2 \mathrm{H}_{2} \mathrm{O}$ diambil sebanyak 0,38 g, kemudian dilarutkan dengan larutan asam dan dimasukkan ke dalam labu ukur 100 mL kemudian diencerkan hingga batas dengan larutan asam.

\section{Preparasi membran cair}

Membran PTFE direndam ke dalam larutan D2EHPA selama 2 jam

\section{Proses Recovery Perak dari Limbah Fotografi}

Membran PTFE yang telah direndam dengan larutan D2EHPA diletakkan diantara dua bejana yang berisi larutan umpan dan larutan penerima seperti yang ditunjukkan pada Gambar 1. Setelah itu dilakukan pengadukan selama 6 jam. Perlakuan yang sama diterapkan pada setiap proses pemisahan. Setelah fasa umpan dan fasa penerima melalui proses pengadukan, dilakukan pengukuran $\mathrm{pH}$ dengan alat $\mathrm{pH}$ meter untuk mengetahui perubahan $\mathrm{pH}$, sedangkan untuk analisis kandungan ion logam pada fasa umpan dan fasa penerima setelah proses pemisahan dilakukan dengan spektrometer serapan atom.

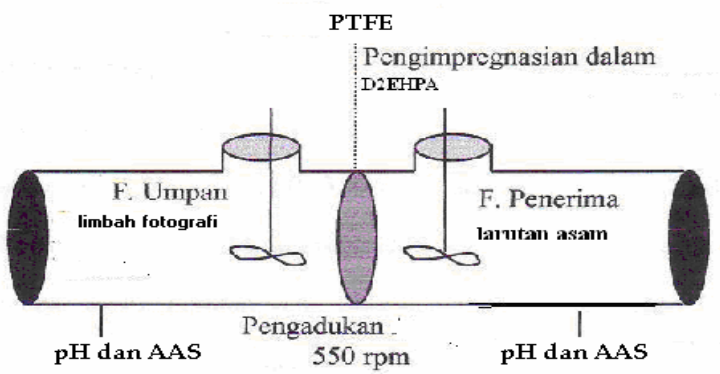

Gambar 1. Alat SLM 


\section{Hasil Dan Pembahasan \\ Penentuan pH optimun}

Perak dalam limbah fotografi berada dalam bentuk kompleks Ag-tiosulfat, dimana kondisinya sangat stabil. Ikatan kompleks tersebut diharapkan dapat diputuskan yaitu dengan mengontrol $\mathrm{pH}$ larutan limbah pada $\mathrm{pH}$ tertentu, sehingga perlu dilakukan variasi $\mathrm{pH}$ umpan yaitu $\mathrm{pH} 1 ; 1,5 ; 2 ; 2,5 ; 3 ; 3,5$ dan 4 sedangkan $\mathrm{pH}$ pada fasa penerima dibuat tetap yaitu 0,75. Hasil transpor ion $\mathrm{Ag}^{+}$dengan variasi $\mathrm{pH}$ umpan ditunjukkan pada Gambar 2.

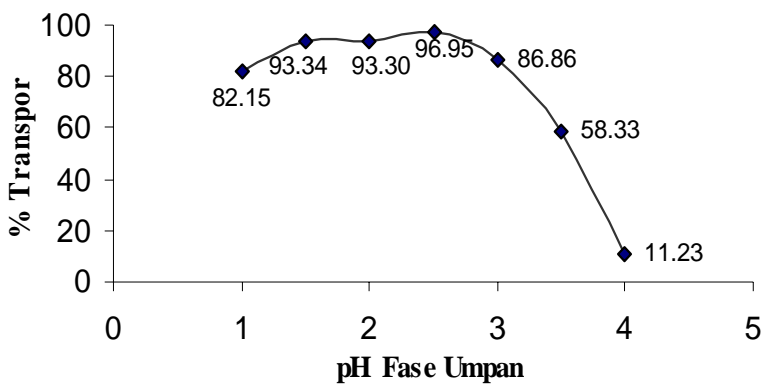

Gambar 2. Pengaruh $\mathrm{pH}$ mula-mula terhadap \% transpor pada fasa umpan

Gambar 2 menunjukkan bahwa proses pemisahan optimum $\mathrm{Ag}^{+}$diperoleh pada $\mathrm{pH}$ 2,5. Hal ini dikarenakan pada $\mathrm{pH}$ rendah kompleks Ag-tiosulfat tidak stabil dan mengalami penguraian dengan pembentukan koloidal sulfur dan sulfur oksida sebagaimana persamaan reaksi berikut (Songkroah et al., 2003):

$$
\begin{aligned}
& 2 \mathrm{H}^{+}+\mathrm{Ag}\left(\mathrm{S}_{2} \mathrm{O}_{3}\right)_{2}{ }^{3-} \rightarrow \mathrm{Ag}^{+}+\left[\mathrm{HS}_{2} \mathrm{O}_{3}-\right] \rightarrow \\
& \mathrm{Ag}^{+}+\mathrm{HSO}_{3}{ }^{-}+\mathrm{S} \rightarrow \mathrm{Ag}^{+}+\mathrm{SO}_{2}+\mathrm{S}+\mathrm{H}_{2} \mathrm{O}
\end{aligned}
$$

Berdasarkan reaksi tersebut pada $\mathrm{pH}$ rendah sejumlah tiosulfat yang berikatan dengan Ag jumlahnya akan menurun dan kompleksitas Ag-tiosulfat semakin sedikit. Oleh karena itu ion $\mathrm{Ag}^{+}$dalam keadaan bebas akan semakin besar jumlahnya sehingga dapat dipisahkan dari limbah fotografi tersebut.

Penguraian kompleks Ag-tiosulfat ini sangat diharapkan karena dalam penelitian ini digunakan senyawa pembawa D2EHPA yang dapat melepaskan ion $\mathrm{H}^{+}$sehingga bermuatan negatif dan hanya mampu memindahkan suatu atom atau senyawa yang memiliki muatan positif. Ion $\mathrm{Ag}^{+}$diharapkan dalam bentuk bebas sehingga dapat ditranspor ke fasa penerima. Di samping itu dengan penggunaan senyawa pembawa asam D2EHPA dengan pKa 1,4 (De et al., 1970) dapat melepaskan $\mathrm{H}^{+}$pada larutan umpan juga dipengaruhi oleh $\mathrm{pH}$ larutan. Ketika $\mathrm{pH}$ larutan umpan terlalu rendah maka senyawa asam cenderung menekan pelepasan $\mathrm{H}^{+}$, karena jumlah ion $\mathrm{H}^{+}$dalam larutan umpan sangat tinggi sehingga kesetimbangan akan bergerak ke kiri sesuai dengan asas Le Chatelier.

$$
\mathrm{HC} \leftrightarrow \mathrm{H}^{+}+\mathrm{C}^{-}
$$

Dimana HC adalah senyawa pembawa D2EHPA dan $\mathrm{C}^{-}$adalah anion senyawa pembawa D2EHPA yang telah melepaskan $\mathrm{H}^{+}$. Proses transpor ion $\mathrm{Ag}^{+}$secara singkat adalah sebagai berikut:

$$
\begin{aligned}
& \mathrm{Ag}^{+}+\mathrm{HC}_{(\text {membran })} \stackrel{\text { pengekstkesian }}{\longrightarrow} \mathrm{AgC}_{(\text {membran })}+\mathrm{H}^{+} \\
& \mathrm{AgC}_{(\text {membran })}+\mathrm{H}^{+} \stackrel{\text { pelepasan }}{\longrightarrow} \mathrm{HC}_{(\text {membran })}+\mathrm{Ag}^{+} \\
& \text {Senyawa pembawa D2EHPA (HC) }
\end{aligned}
$$
sebagaimana disajikan pada Gambar 3 akan kehilangan satu proton dan berinteraksi dengan ion $\mathrm{Ag}^{+}$membentuk suatu kompleks senyawa pembawalogam (AgC) pada membran. Kompleks ini akan berdifusi ke antarmuka sisi fasa penerima, dimana selanjutnya membebaskan ion $\mathrm{Ag}^{+}$ke dalam larutan penerima. Secara bersamaan mengambil proton dari larutan penerima dan senyawa pembawa HC berdifusi kembali ke larutan umpan-permukaan SLM untuk mengambil ion logam lainnya dan proses terus berlanjut dimana senyawa pembawa akan bolak-balik antara sisi antar muka larutan umpan dan larutan penerima.

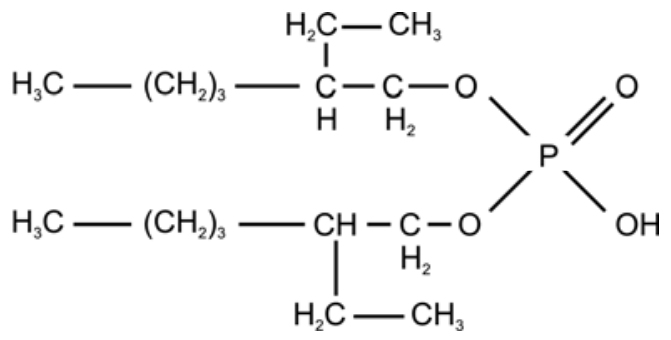

Gambar 3. Struktur D2EHPA

Pada $\mathrm{pH}$ yang lebih rendah dari $\mathrm{pH}$ optimumnya $(2,5)$ akan memberikan hasil pemisahan yang relatif kecil, karena terbentuknya endapan sulfur (Svehla, 1982). Endapan ini menyebabkan permukaaan membran terhalang sehingga proses interaksi ion $\mathrm{Ag}^{+}$dengan senyawa pembawa D2EHPA menjadi terbatas, yang menyebabkan transpor ion $\mathrm{Ag}^{+}$pada $\mathrm{pH}$ 1; 1,5 dan 2 menjadi kecil.

Selain itu adanya gaya dorong pada sistem ini, yaitu perbedaan $\mathrm{pH}$ larutan umpan dan penerima akan mempengaruhi harga $\mathrm{kd}_{\mathrm{f}} \mathrm{Ag}$ larutan umpan dan $\mathrm{Kd}_{\mathrm{s}} \mathrm{Ag}$ larutan penerima. Perbedaan $\mathrm{Kd}_{\mathrm{f}}$ larutan umpan dan $\mathrm{Kd}_{\mathrm{s}}$ larutan penerima optimal pada $\mathrm{pH}$ larutan umpan 2,5 dengan $\mathrm{pH}$ larutan penerima 0,75.

Proses transpor ion perak dari limbah fotografi dapat diketahui pula dengan cara menentukan $\mathrm{pH}$ larutan fasa umpan dan penerima setelah proses pemisahan selama 6 jam. Berdasarkan hasil penelitian pada berbagai variasi $\mathrm{pH}$ terjadi penurunan $\mathrm{pH}$ pada fasa umpan dan kenaikan $\mathrm{pH}$ pada fasa penerima akibat berpindahnya ion $\mathrm{H}^{+}$dari fasa umpan ke fasa penerima, sebagaimana ditunjukkan pada Tabel 1 dan Tabel 2. 
Tabel 1. Perubahan pH pada larutan umpan pada berbagai variasi $\mathrm{pH}$

\begin{tabular}{lcc}
\hline \multirow{2}{*}{ Larutan } & \multicolumn{2}{c}{ Pengukuran $\mathrm{pH}$} \\
\cline { 2 - 3 } & $\begin{array}{c}\text { Sebelum } \\
\text { pengadukan }\end{array}$ & $\begin{array}{c}\text { Setelah } \\
\text { pengadukan }\end{array}$ \\
\hline $\mathrm{FU}_{1}(\mathrm{pH}: 1)$ & 1.003 & 1,0 \\
$\mathrm{FU}_{2}(\mathrm{pH}: 1,5)$ & 1,504 & 1,49 \\
$\mathrm{FU}_{3}(\mathrm{pH}: 2)$ & 2,046 & 2,01 \\
$\mathrm{FU}_{4}(\mathrm{pH}: 2,5)$ & 2,683 & 2,48 \\
$\mathrm{FU}_{5}(\mathrm{pH}: 3)$ & 3,143 & 3,01 \\
$\mathrm{FU}_{6}(\mathrm{pH}: 3,5)$ & 3,501 & 3,47 \\
$\mathrm{FU}_{7}(\mathrm{pH}: 4)$ & 4,006 & 3,98 \\
\hline
\end{tabular}

Tabel 2. Perubahan pH pada larutan penerima pada berbagai variasi $\mathrm{pH}$

\begin{tabular}{ccc}
\hline \multirow{2}{*}{ Larutan } & \multicolumn{2}{c}{ Pengukuran $\mathrm{pH}$} \\
\cline { 2 - 3 } & $\begin{array}{c}\text { Sebelum } \\
\text { pengadukan }\end{array}$ & $\begin{array}{c}\text { Setelah } \\
\text { pengadukan }\end{array}$ \\
\hline $\mathrm{FP}_{1}(\mathrm{pH}: 0,75)$ & 0,749 & 0.831 \\
$\mathrm{FP}_{2}(\mathrm{pH}: 0,75)$ & 0,749 & 0,849 \\
$\mathrm{FP}_{3}(\mathrm{pH}: 0,75)$ & 0,749 & 0,752 \\
$\mathrm{FP}_{4}(\mathrm{pH}: 0,75)$ & 0,749 & 0,753 \\
$\mathrm{FP}_{5}(\mathrm{pH}: 0,75)$ & 0,749 & 0,753 \\
$\mathrm{FP}_{6}(\mathrm{pH}: 0,75)$ & 0,749 & 0,754 \\
$\mathrm{FP}_{7}(\mathrm{pH}: 0,75)$ & 0,749 & 0,767 \\
\hline
\end{tabular}

\section{Penentuan larutan penerima optimum}

Pada dasarnya driving force transpor-tanding pada proses pemisahan dengan SLM adalah perbedaan $\mathrm{pH}$ antara larutan umpan dan penerima (Misra and Gill, 1996), sehingga $\mathrm{pH}$ larutan penerima dikondisikan pada $\mathrm{pH}$ sekecil mungkin yaitu sebesar 0,75. Untuk mempercepat proses pelepasan ion $\mathrm{Ag}^{+}$dari senyawa pembawa D2EHPA baik dengan pembentukan endapan maupun dengan membentuk senyawa kompleks dengan ion $\mathrm{Ag}^{+}$, maka dilakukan dengan cara memvariasi larutan penerima yaitu larutan $\mathrm{HCl}, \mathrm{HCl}-\mathrm{EDTA}, \mathrm{HNO}_{3}$, $\mathrm{HNO}_{3}$-EDTA, $\mathrm{H}_{3} \mathrm{PO}_{4}$ dan $\mathrm{H}_{3} \mathrm{PO}_{4}$-EDTA. Hasil transpor ion $\mathrm{Ag}^{+}$dengan variasi larutan penerima sebagaimana ditunjukkan pada Tabel 3.

Berdasarkan Tabel 3 menunjukkan bahwa larutan penerima HCl-EDTA memberikan hasil \% transpor $\mathrm{Ag}^{+}$ pada fasa penerima paling baik yaitu 63,855\% dibandingkan jenis penerima lainnya $\left(\mathrm{HNO}_{3}\right.$-EDTA, $\mathrm{H}_{3} \mathrm{PO}_{4}$-EDTA, $\mathrm{HCl}, \mathrm{HNO}_{3}$ dan $\mathrm{H}_{3} \mathrm{PO}_{4}$ ). Hal ini karena larutan penerima $\mathrm{HCl}$-EDTA, yang terdiri dari EDTA dan $\mathrm{HCl}$ memiliki peran masing-masing yang saling mendukung dalam proses penarikan ion $\mathrm{Ag}^{+}$dari senyawa pembawa pada membran. EDTA memiliki peran menarik ion $\mathrm{Ag}^{+}$dengan membentuk senyawa kompleks sebagamana reaksi dibawah ini:

$$
\mathrm{Ag}^{+}+\mathrm{EDTA} \leftrightarrow[\mathrm{Ag}(\mathrm{EDTA})]^{+}
$$

Tabel 3. Pengaruh larutan penerima terhadap transpor

\begin{tabular}{cccc}
\hline \multirow{2}{*}{$\begin{array}{c}\text { Larutan } \\
\text { penerima }\end{array}$} & \begin{tabular}{c} 
\% Tranpor \\
Ag pada \\
fasa \\
\cline { 3 - 4 }
\end{tabular} & \multicolumn{2}{c}{ \% $\mathrm{Ag}^{+}$yang tertinggal } \\
\cline { 3 - 4 } $\mathrm{HCl}$ & 3,614 & $\begin{array}{c}\text { dalam fasa } \\
\text { penerima }\end{array}$ & $\begin{array}{c}\text { pada } \\
\text { membran }\end{array}$ \\
\hline $\mathrm{HCl}$-EDTA & 63,855 & 36,144 & 91,567 \\
$\mathrm{HNO}_{3}$ & $<3,012$ & 22,892 & $<74,0006$ \\
$\mathrm{HNO}_{3}$-EDTA & 13,253 & 3,614 & 83,133 \\
$\mathrm{H}_{3} \mathrm{PO}_{4}$ & 1,205 & 10,843 & 87,952 \\
$\mathrm{H}_{3} \mathrm{PO}_{4}$-EDTA & 2,410 & 32,530 & 65,060 \\
\hline
\end{tabular}

$\mathrm{HCl}$ mampu menarik ion $\mathrm{Ag}^{+}$dari senyawa pembawa D2EHPA pada membran dengan interaksi yang paling kuat dibandingkan dangan reaksi ion $\mathrm{Ag}^{+}$ dengan $\mathrm{H}_{3} \mathrm{PO}_{4}$ ataupun dengan $\mathrm{HNO}_{3}$. Hal ini karena endapan $\mathrm{AgCl}$ mudah terbentuk dibandingkan dengan $\mathrm{Ag}_{3} \mathrm{PO}_{4}$ (Skoog et al., 1996), sehingga mudah terjadi pergeseran arah kesetimbangan ke kanan dari senyawa pembawa ke larutan penerimanya. Pada penelitian ini tidak didapatkan endapan AgCl karena konsentrasi ion $\mathrm{Ag}^{+}$dalam limbah yang diperoleh relatif kecil yaitu 8 ppm.

$$
\mathrm{Ag}^{+}+\mathrm{Cl}^{-} \leftrightarrow \mathrm{AgCl}
$$

Pada larutan penerima $\mathrm{H}_{3} \mathrm{PO}_{4}$-EDTA, seharusnya adanya ion fosfat dapat menarik ion $\mathrm{Ag}^{+}$ (membantu proses pelepasan ion perak dari senyawa pembawa) lebih mudah dengan membentuk senyawa $\mathrm{Ag}_{3} \mathrm{PO}_{4}$ dibandingkan larutan penerima $\mathrm{HNO}_{3}-$ EDTA, sehingga akan memberikan hasil pemisahan yang lebih baik dibandingkan larutan penerima $\mathrm{HNO}_{3}$-EDTA. Sebaliknya larutan penerima $\mathrm{HNO}_{3}-$ EDTA memberikan hasil pemisahan ion $\mathrm{Ag}^{+}$yang lebih baik dibandingkan dengan larutan penerima $\mathrm{HNO}_{3}, \mathrm{HCl}, \mathrm{H}_{3} \mathrm{PO}_{4}$ maupun $\mathrm{H}_{3} \mathrm{PO}_{4}$-EDTA, dikarenakan $\mathrm{H}_{3} \mathrm{PO}_{4}$ merupakan asam yang lebih lemah daripada $\mathrm{HNO}_{3}$ (Kennedy, 1990), sehingga $\mathrm{H}_{3} \mathrm{PO}_{4}$ akan melepaskan ketiga $\mathrm{H}^{+}$secara bertahap seperti reaksi dibawah ini:

$$
\begin{aligned}
\mathrm{H}_{3} \mathrm{PO}_{4}+\mathrm{H}_{2} \mathrm{O} \leftrightarrow \mathrm{H}_{2} \mathrm{PO}_{4}^{-}+\mathrm{H}_{3} \mathrm{O}^{+} \\
\mathrm{K}_{1}=\frac{\left[\mathrm{H}_{2} \mathrm{PO}_{4}^{-}\right] \cdot\left[\mathrm{H}_{3} \mathrm{O}\right]^{+}}{\left[\mathrm{H}_{3} \mathrm{PO}_{4}\right]}=7,1 \times 10^{-3}
\end{aligned}
$$




$$
\begin{aligned}
\mathrm{H}_{2} \mathrm{PO}_{4}^{-}+\mathrm{H}_{2} \mathrm{O} \leftrightarrow \mathrm{HPO}_{4}^{-2}+\mathrm{H}_{3} \mathrm{O}^{+} \\
\mathrm{K}_{2}=\frac{\left[\mathrm{HPO}_{4}^{-2}\right] \cdot\left[\mathrm{H}_{3} \mathrm{O}\right]^{+}}{\left[\mathrm{H}_{2} \mathrm{PO}_{4}^{-}\right]}=6,3 \times 10^{-8} \\
\mathrm{HPO}_{4}^{-2}+\mathrm{H}_{2} \mathrm{O} \leftrightarrow \mathrm{PO}_{4}^{-3}+\mathrm{H}_{3} \mathrm{O}^{+} \\
\mathrm{K}_{3}=\frac{\left[\mathrm{PO}_{4}^{-3}\right] \cdot\left[\mathrm{H}_{3} \mathrm{O}\right]^{+}}{\left[\mathrm{HPO}_{4}^{-2}\right]}=4,2 \times 10^{-13}
\end{aligned}
$$

Reaksi yang terjadi pada proses pemisahan dengan variasi larutan penerima dapat dituliskan sebagai berikut:

$$
\mathrm{Ag}^{+}+\mathrm{HC}_{(\text {membran })} \stackrel{\text { pengeksthssian }}{\longrightarrow} \mathrm{AgC}_{(\text {membran })}+\mathrm{H}^{+}
$$

$$
\begin{aligned}
\mathrm{AgC}_{(\text {membran })}+\mathrm{H}^{+}+\text {EDTA } \stackrel{\text { Pelepasan }}{\longrightarrow} \mathrm{HC}_{(\text {membran })} \\
+[\mathrm{Ag}(\mathrm{EDTA})]^{+}
\end{aligned}
$$

$\mathrm{AgC}_{(\text {membran) }}+\mathrm{H}^{+}+\mathrm{X}^{-} \stackrel{\text { Pelepasan }}{\longrightarrow} \mathrm{HC}_{(\text {membran) }}+\mathrm{AgX}$

Mekanisme transport dengan variasi larutan penerima seperti ditunjukkan pada Gambar 4.

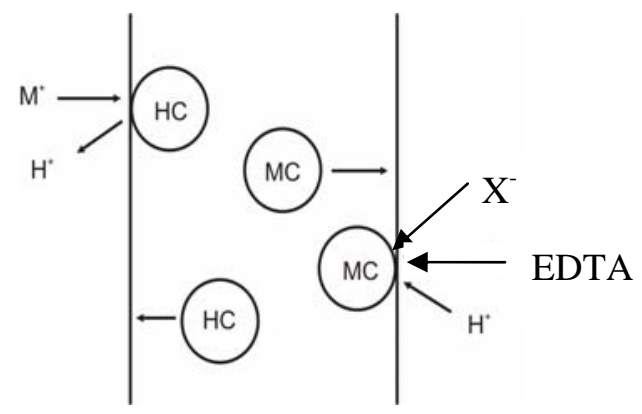

Gambar 4. Mekanisme counter -transport dengan variasi larutan Penerima

Proses transpor ion perak dari limbah fotografi pada berbagai variasi larutan penerima terjadi penurunan $\mathrm{pH}$ larutan umpan dan kenaikan $\mathrm{pH}$ larutan penerima, akibat adanya transpor ion $\mathrm{H}^{+}$dari larutan penerima ke larutan umpan sebagai ion tanding dari transpor ion $\mathrm{Ag}^{+}$, seperti ditunjukkan pada Tabel 4 dan Tabel 5.
Tabel 4. Perubahan pH pada berbagai variasi larutan penerima

\begin{tabular}{lcc}
\hline \multirow{2}{*}{$\begin{array}{c}\text { Larutan Fasa } \\
\text { Penerima (FP) }\end{array}$} & \multicolumn{2}{c}{ Peng ukuran $\mathrm{pH}$} \\
\cline { 2 - 3 } & $\begin{array}{c}\text { Sebelum } \\
\text { Pengadukan }\end{array}$ & $\begin{array}{c}\text { Setelah } \\
\text { Pengadukan }\end{array}$ \\
\hline $\mathrm{FP}_{1}(\mathrm{HCl})$ & 0,75 & 0,753 \\
$\mathrm{FP}_{2}(\mathrm{HCl}-\mathrm{EDTA})$ & 0,749 & 0,763 \\
$\mathrm{FP}_{3}\left(\mathrm{HNO}_{3}\right)$ & 0,75 & 0,761 \\
$\mathrm{FP}_{4}\left(\mathrm{HNO}_{3}\right.$-EDTA) & 0,751 & 0,761 \\
$\mathrm{FP}_{5}\left(\mathrm{H}_{3} \mathrm{PO}_{4}\right)$ & 0,75 & 0,758 \\
$\mathrm{FP}_{6}\left(\mathrm{H}_{3} \mathrm{PO}_{4}\right.$-EDTA $)$ & 0,749 & 0,764 \\
\hline
\end{tabular}

Tabel 5. Perubahan pH pada berbagai variasi larutan umpan

\begin{tabular}{lcc}
\hline \multirow{2}{*}{$\begin{array}{c}\text { Larutan Fasa } \\
\text { Umpan (FU) } \\
\text { Pengenceran 10x }\end{array}$} & \multicolumn{2}{c}{ Pengukuran $\mathrm{pH}$} \\
\cline { 2 - 3 } & $\begin{array}{c}\text { Sebelum } \\
\text { Pengadukan }\end{array}$ & $\begin{array}{c}\text { Setelah } \\
\text { Pengadukan }\end{array}$ \\
\hline $\mathrm{FU}_{1}(\mathrm{pH}: 2,5)$ & 2,504 & 2,484 \\
$\mathrm{FU}_{2}(\mathrm{pH}: 2,5)$ & 2,504 & 2,486 \\
$\mathrm{FU}_{3}(\mathrm{pH}: 2,5)$ & 2,504 & 2,368 \\
$\mathrm{FU}_{4}(\mathrm{pH}: 2,5)$ & 2,504 & 2,11 \\
$\mathrm{FU}_{5}(\mathrm{pH}: 2,5)$ & 2,504 & 2,473 \\
$\mathrm{FU}_{6}(\mathrm{pH}: 2,5)$ & 2,504 & 2,48 \\
\hline
\end{tabular}

\section{Penentuan konsentrasi larutan umpan optimum}

Hasil konsentrasi $\mathrm{Ag}^{+}$mula-mula dan konsentrasi $\mathrm{Ag}^{+}$pada larutan penerima disajikan pada Tabel 6.

Tabel 6. Pengaruh konsentrasi perak terhadap efisiensi transpor

\begin{tabular}{ccc}
\hline Konsentrasi & \multicolumn{2}{c}{ Konsentrasi $\mathrm{Ag}^{+}(\mathrm{ppm})$} \\
\cline { 2 - 3 } $\begin{array}{c}\text { Limbah } \\
\text { Fotografi }\end{array}$ & mula-mula & $\begin{array}{c}\text { pada larutan } \\
\text { penerima }\end{array}$ \\
\hline Pengenceran 10 x & 0,83 & 0,53 \\
Pengenceran 0 x & 11,00 & 0,46 \\
Pemekatan 0,5 x & 15,50 & 0,29 \\
\hline
\end{tabular}

Dari Tabel 6 menunjukkan bahwa semakin besar konsentrasi, hasil pemisahan semakin menurun. Hal ini dikarenakan kejenuhan pori-pori membran oleh senyawa pembawa-logam (Alguacil dan Alonso, 2004; Martynia, 2003), sehingga menyebabkan proses pelepasan ion $\mathrm{Ag}^{+}$ke fasa penerima menjadi terganggu. Selain faktor di atas penguraian kompleks perak-tiosulfat akan menghasilkan endapan sulfur 
(Svehla,1982). Perubahan pH larutan pada larutan umpan dan penerima dapat dilihat melalui Tabel 7 dan Tabel 8.

Tabel 7. Perubahan pH larutan umpan

\begin{tabular}{ccc}
\hline Fasa Umpan (FU) & \multicolumn{2}{c}{ Pengukuran pH } \\
\cline { 2 - 3 } Variasi Konsentrasi & $\begin{array}{c}\text { Sebelum } \\
\text { Pengadukan }\end{array}$ & $\begin{array}{c}\text { Setelah } \\
\text { Pengadukan }\end{array}$ \\
\hline $\mathrm{FU}_{1}$ pengenceran 10x & 2,504 & 2,486 \\
$\mathrm{FU}_{2}$ Pengenceran 0x & 2,492 & 2,388 \\
$\mathrm{FU}_{3}$ Pemekatan 1/2x & 2,511 & 2,477 \\
\hline
\end{tabular}

Tabel 8. Perubahan pH pada berbagai larutan penerima

\begin{tabular}{lcc}
\hline \multirow{2}{*}{ Fasa Penerima (FP) } & \multicolumn{2}{c}{ Pengukuran $\mathrm{pH}$} \\
\cline { 2 - 3 } & $\begin{array}{c}\text { Sebelum } \\
\text { Pengadukan }\end{array}$ & $\begin{array}{c}\text { Setelah } \\
\text { Pengadukan }\end{array}$ \\
\hline $\mathrm{FP}_{1}$ (HCl-EDTA) & 0,753 & 1,276 \\
$\mathrm{FP}_{2}$ (HCl-EDTA) & 0,753 & 0,766 \\
$\mathrm{FP}_{3}$ (HCl-EDTA) & 0,753 & 0,764 \\
\hline
\end{tabular}

Berdasarkan Tabel 7 dan 8 dapat diketahui terjadi kenaikan $\mathrm{pH}$ larutan penerima dan penurunan $\mathrm{pH}$ larutan umpan akibat adanya transpor ion $\mathrm{H}^{+}$dari larutan penerima ke larutan umpan sebagai ion tanding pada transpor ion $\mathrm{Ag}^{+}$.

\section{Kesimpulan}

Berdasarkan hasil pengamatan terhadap proses pemisahan ion perak dari limbah fotografi dengan teknik membran cair berpendukung dapat ditarik kesimpulan bahwa ion perak dari limbah fotografi dapat diperoleh kembali dengan teknik membran cair berpendukung pada kondisi terbaik yaitu konsentrasi larutan limbah yang rendah, $\mathrm{pH}$ larutan umpan 2,5 dan larutan penerima HCl-EDTA dengan $\mathrm{pH}$ larutan 0,75.

\section{Saran}

Penelitian lanjutan tentang recovery perak dari limbah fotografi melalui teknik SLM dengan variasi senyawa pembawa serta waktu pengadukan perlu dilakukan untuk mendapatkan hasil yang lebih optimal dalam transpor ion perak dari limbah fotografi.

\section{Daftar Pustaka}

Alguacil, J. H., and Alonso, M., (2004), "Separation of Zinc(II) from Cobalt (II) Solutions Using Supported
Liquid Membrane with DP-8R (di-2-ethylhexyl phosphoric Acid) as a Carrier”, J. Separation and Purification Technology, 41, 179-184.

De, A., Khopkar, S., and Chalmer, R. A., (1970), "Solvent Extraction of Metals", 81-100, Van Nostrand Reinhollom, London.

Hadikawuryan, D.S., (2005), "Pemisahan Logam Perak (I) Menggunakan Membran Cair Emulsi (ELM) dengan Pembawa Sinergi”, Skripsi, Universitas Diponegoro, Semarang.

Kennedy, J.H., (1990), “Analytical Chemistry, Principles”, 259-264, Saunders College Publishing, California.

Martynia, D., (2003), "Pemisahan Logam Berat Menggunakan Membran Cair Berpendukung Dengan Senyawa Pembawa Asam Di-2-Etilheksilfosfat”, Skripsi, Universitas Diponegoro, Semarang.

Misra, B. M., and Gill, J. S., (1996), "Supported Liquid Membranes In Metal Separation”, 361-368, American Chemical Society, Washington

Rahmawati, A., (2005), "Pemisahan Selektif Logam Perak (I) Menggunakan Membran Cair Berpendukung (SLM)”, Skripsi, Universitas Diponegoro, Semarang.

Santoso, I., (2000), "Recovery Perak (I) dari Limbah Cuci/Cetak Foto dengan Menggunakan Teknik Membran Cair Emulsi”, Tesis, Bidang Khusus Kimia Analitik, Program Studi Kimia, Program Pascasarjana, ITB

Skoog, D.A., West, D.M., and Holler., (1996), "Fundamental of Analitycal Chemistry", 510, 611624, Saunders College Publishing, California.

Songkroah, C., Nakbanpote, C., and Thiravetyan, P., (2003), "Recovery of Silver- Thiosulphate Complexes with Chitin”, Process Biochemistry Journal, 39, 1553-1559.

Svehla, G., (1982), "Vogel's Textbook of Macro and Semimicro Qualitative Inorganic Analysis”, 305-306, Logman, London. 